\title{
遠心力を利用した細骨材の保有水試験方法
}

\section{TESTING METHOD FOR RETAINED WATER OF FINE AGGREGATE BY UTILIZING CENTRIFUGAL FORCE}

\author{
过 幸 和* ·二羽淳一郎**・伊 東 靖 郎***・岡 村 \\ 甫 \\ By Yukikazu TSUJI, Junichiro NIWA, Yasuro ITO and Hä̈me OKAMURA
}

\begin{abstract}
It was presumed that in reality fine aggregate would hold surface moisture peculiar to its own in addition to water defined by the JIS testing method for content of absorbed moisture of fine aggregate. The authors tried to clarify the actual conditions of the retained water by a new testing method by utilizing centrifugal force. As the results of a series of experimental studies, a fundamental conception of the testing method could be proposed. This testing method can measure the retained water as the sum of absorbed moisture and surface moisture of fine aggregate. Besides the conception, basic test results were presented.

Keywords : testing method, retained water, fine aggregate, absorbed moisture, surface moisture
\end{abstract}

\section{1. まえがき}

細骨材の表面水率が大幅に変動すると, JIS A 1109 による表面乾燥飽水状態を基準にして表面水率を補正し ても，フレッシュコンクリートの性状は異なったものに なることが，これまでに報告されている1) -3).この現象 を，主として細骨材の種類等により異なる細骨材に保有 された水の存在によるものと考えた。 すでに著者らの一 人は, JIS A 1207 「土の遠心含水当量試験方法」に規 定する遠心分離機を用い，細骨材之水の混合物に遠心力 を作用させて脱水処理を行うことにより，細骨材の表面 吸着水を試験する方法を提案した ${ }^{3)}$.この方法では, 所 定の含水率になるように調整した試料を容器に詰めて, これに遠心力を所定の時間作用させて脱水した後に残る 水分を，細骨材の表面吸着水と定義した。この試験によ り，種類や粒度の異なる細骨材の表面吸着水を定量的に

* 正会員 工博 群馬大学助教授 工学部建設工学科 ( ₹376 桐生市天神町 1-5-1)

** 正会員 工博 山梨大学助教授 工学部土木工学科 ( ₹400 甲府市武田 4-3-11)

*** 正会員 工博 リブコンエンジニアリング (株) 代表取締役社長 (テ162 新宿区市谷本村町 36 第 6 ミナミビル)

**** 正会員 工博 東京大学教授 工学部土木工学科 ( T113 文京区本郷 7-3-1)
評価することができ，また表面吸着水を補正することに より,これまでより品質変動の少ないコンクリートを製 造できるようになった。

しかしながら，この試験方法は，水と細骨材の混合物 を試料とするため, フレッシュコンクリート中における セメントペーストにより分散されている細骨材の状態を 正確にモデル化できていないこと，および，細骨材粒子 が接触している部分に存在する水である接触水も含め, 表面吸着水の物理的意味付けが不十分であることなどの 欠点がある. また，吉兼らは，アスファルト混合物中の アスファルト量の抽出に用いられる遠心脱水機を改造し て，遠心脱水による表乾状態の細骨材を製造する方法を 提案しており されている.

本研究では, 細骨材に保有されている水を細骨材の保 有水と定義し, フライアッシュや高炬スラグ微粉末と水 の混合物中あるいはセメントペースト中に，細骨材を分 散させた状態で遠心力を作用させることにより，その保 有水の定量的な評価を行うことができる，細骨材の保有 水試験方法を提案するものである.

\section{2. 使用材料}

細骨材は, 主として相模川産と大井川産の川砂, 珪砂 
およびモデル細骨材としてのガラス玉を用いた。これら の細骨材は，0.3 mm のふるいを通過するものを取り除 き，粒度曲線が図一1に示す実線のごとくなるように粒 度調整を行ったものを主として用いた。これは, 細骨材 中の微粒分が測定値に及ぼす影響を避け，まず， 0.3 $\mathrm{mm}$ 以上の粗い細骨材について, 保有水を測定し，その 量が細骨材の種類により異なることを，主目的としたた めである、なお，粒度を調整しないものも一部分で用い ている，それぞれの細骨材の品質を表一1に示す.

細骨材の保有水試験における分散材としては, フライ アッシュ, 普通ボルトランドセメントおよび 4 種類の高

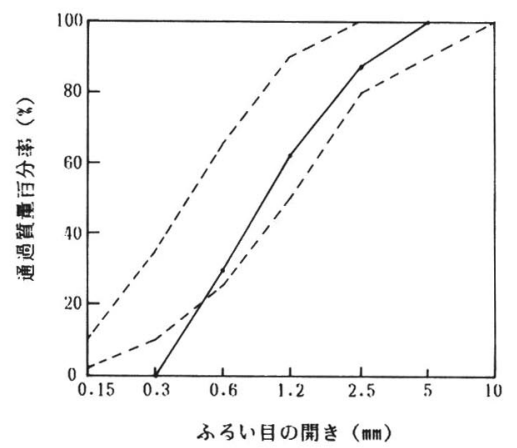

図一1 細骨材の粒度曲線（粒度調整）

\begin{tabular}{|c|c|c|c|c|c|}
\hline 種 類 & 比重 & 粗粒率 & $\begin{array}{c}\text { 実積害 } \\
(\%)\end{array}$ & $\begin{array}{c}\text { 吸水害 } \\
(\%)\end{array}$ & 備考 \\
\hline 相模川産 & 2.58 & 3.20 & 64.3 & 3.01 & \multirow{4}{*}{$\begin{array}{l}\text { 柆度 } \\
\text { 調 }\end{array}$} \\
\hline 大井川産 & 2.57 & 3.20 & 67.3 & 1.65 & \\
\hline 珪砂 & 2.58 & 3.20 & 62.5 & 0.59 & \\
\hline ガラス玉 & 2.45 & 3.20 & 63.8 & 0.05 & \\
\hline 富士川産 & 2.58 & 2.65 & 69.0 & 2.49 & \multirow{7}{*}{ 整度 } \\
\hline 相模川産 & 2.60 & 2.80 & 68.0 & 2.96 & \\
\hline 生駒産 & 2.54 & 2.68 & 67.4 & 1.35 & \\
\hline 錦岡産 & 2.70 & 3.30 & 70.1 & 1.40 & \\
\hline 研砂 & 2.59 & 2.48 & 65.1 & 1.56 & \\
\hline 日向産 & 2.52 & 2.77 & 68.0 & 1.98 & \\
\hline 加古川産 & 2.54 & 3.02 & 65.9 & 1.99 & \\
\hline
\end{tabular}

表一2 分散材の物理的性質

\begin{tabular}{|c|c|c|c|}
\hline & 比重 & 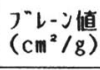 \\
\hline \multicolumn{2}{|c|}{ セメント } & 3.16 & 3340 \\
\hline \multicolumn{2}{|c|}{ フライアッシュ } & 2.19 & 3080 \\
\hline \multirow{4}{*}{$\begin{array}{l}\text { 高 炉 } \\
\text { スラグ } \\
\text { 铰粉末 }\end{array}$} & B1 & 2.90 & 3760 \\
\hline & $B 2$ & 2.90 & 3290 \\
\hline & B3 & 2.90 & 5680 \\
\hline & B4 & 2.90 & 7860 \\
\hline
\end{tabular}

炬スラグ微粉末を用いた。それぞれの物理的性質を表一 2 に示す。

\section{3. 保有水の試験方法}

試料に遠心力を作用させる遠心分離機は, JIS A 1207「土の遠心含水当量試験方法」に規定するものを用 いたが, 試料を収める容器は, 以下のように改良した。 試料容器は, 図一 2 および写真一1に示すように, 内径 が $5 \mathrm{~cm}$ で高さが $10 \mathrm{~cm}$ の塩化ビニール製の円筒を用い ている．上面には厚さが $9 \mathrm{~mm}$ のアクリル製の円盤を， また，下面にはふるい目が $0.15 \mathrm{~mm}$ の金網の下に沪紙 と厚さが $1.6 \mathrm{~mm}$ の打ち抜き鉄板からなる汇過部を設け て, 水分が排出できるようにした，その下に試料容器と 同じ内径で, 高さが $5 \mathrm{~cm}$ の塩化ビニール製の円筒とそ の下面に厚さが $9 \mathrm{~mm}$ のアクリル製の円盤を接着した排 出水を収納する容器を設けた。この容器の中には, 遠心 力により排出した水分が, 遠心分離機を止めたときに逆 流しないように, 排出水を吸収させる脱脂綿を挿入して いる.
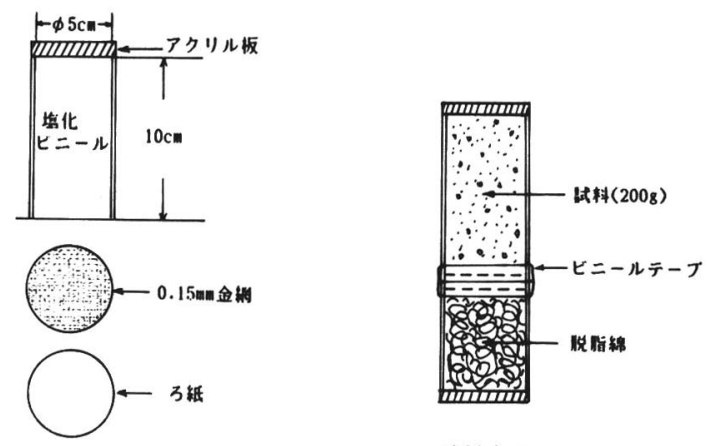

試料容器

\section{図一2 遠心分離機の試料容器}

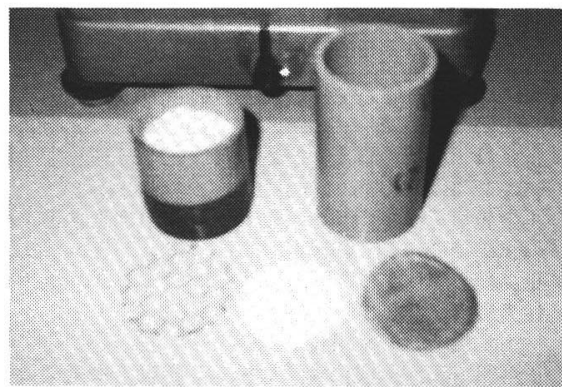




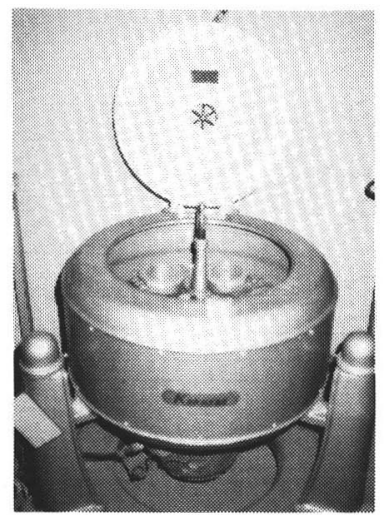

写真一2 遠心分離機の外観

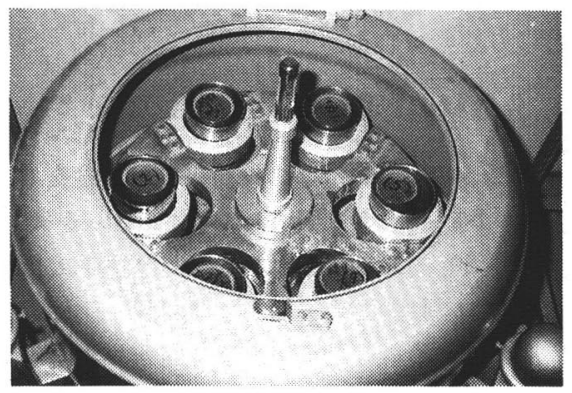

写真一3 試料容器を設置した遠心分離機

容器に入れる試料の重量は, 約 $200 \mathrm{~g}$ である. JIS A 1207 に規定するグーチるつぼを用いず，このような容 器を使用したのは, グーチるつぼに収まる試料が約 $5 \mathrm{~g}$ と非常に少量のため測定值にばらつきが大きいこと，お よび，水分を含む試料をグーチるつぼに入れて遠心力を 作用させると空気が試料中を通過して乾燥するため容器 全体を密封にしなければならないことが，予備実験から 明らかになったためである．写真一 2 に, 遠心分離機の 外観を, また, 写真一3に, 試料容器を設置した状況を それぞれ示す.試料は 1 度に 6 個収納することができる.

\section{4. 細骨材, 水, 分散材の分布状態 および保有水}

細骨材と水の混合物における両者の状態を模式図で示 すと, 図一3のように表わすことができる. 図一3(a) は, 水分が細骨材の間隙に十分満たされた状態である.

これに対して, 図一3(b) は, 細骨材の間隙に気泡が 存在する状態であり, 参考文献 3 ) で提案した細骨材と 水の混合物に遠心力を作用させた後の状態は, この分類 に含まれる．この状態の細骨材には，保有水とともに， 細骨材粒子が接触する部分に, 各粒子間に共有されてい る接触水が存在している.この接触水は, 細骨材の表面 の形状, 岩質および粒度などによって大きく異なってく

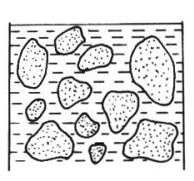

(a)

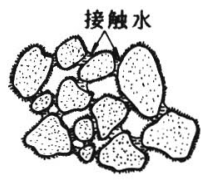

(b)

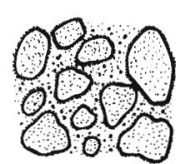

(c)
図一3 細骨材，水および分散材の分布状態

る. 細骨材と水の混合物では, この接触水を取り除き, 接触水の影響を無視できる状態にすることは困難であっ て，保有水のみを評価できない欠点がある.

細骨材間の接触水の影響を取り除くために, 細骨材よ りもさらに粒度の細かい粉体を混入することにより, 接 触部を粉体で置換することを考案した。すなわち，細骨 材を粉体中に分散させることにより，図一3(c) に示す ような細骨材同士間の接触水を含まない, 保有水のみが 存在する状態を創ることができるのである.

分散材としての粉末には, フライアッシュ, 高炉スラ グ微粉末およびセメント等が考えられる.なお，セメン トを用いれば,ここのうな細骨材の状態は, フレッシュ モルタル中の状態をモデル化できることになる．分散材 の量としては，細骨材同士を接触させないように，少な くとも細骨材の空隙に相当する量が必要であり, 細骨材 と分散材の容積比で 2.5 程度までと考えられる.

\section{5. 保有水の評価方法}

細骨材には，粒度分布を図一1に示すように調整した ガラス玉, 相模川砂・珪砂および大井川砂を用い，また 分散材としてはフライアッシュを用いた試料を, 回転数 が $1488 \mathrm{rpm}$, 遠心力に換算して $438 \mathrm{~g}$ ( $\mathrm{g}$ は重力加速度) の脱水処理を 30 分間行った. その後, 細骨材, 分散材 および水の混合物中に残った水量を $110^{\circ} \mathrm{C}$ の乾燥器で 絶乾状態にすることにより測定し，その重量と分散材の 重量の比を, 混合物中の含水率と定義して示したのが図 -4である. 細骨材と分散材の重量比を, 2.5 まで変化 させている，なお，遠心力作用前には，フライアッシュ 自体の含水率を重量比で $35 \%$ とし, 細骨材には含水率 で $5 \%$ の水量をあらかじめ調整したため，この含水量 も含水率の計算に考慮すると，たとえば，細骨材・分散 材比が 2.0 の場合に，混合物中の含水率は $45 \%$ となっ ていた。

細骨材にガラス玉を用いた場合には，遠心力作用後の 混合物中の含水率は, ガラス玉の増加とともにわずかな がら増えているものの, その増加率は微小である.これ に対し，相模川砂を用いた場合には，砂の量に伴って， 混合物中の含水率がほぼ直線的に増加している.

このように, 試料中の細骨材の割合が増加するととも に, 試料中に残った水分を分散材のフライアッシュの重 


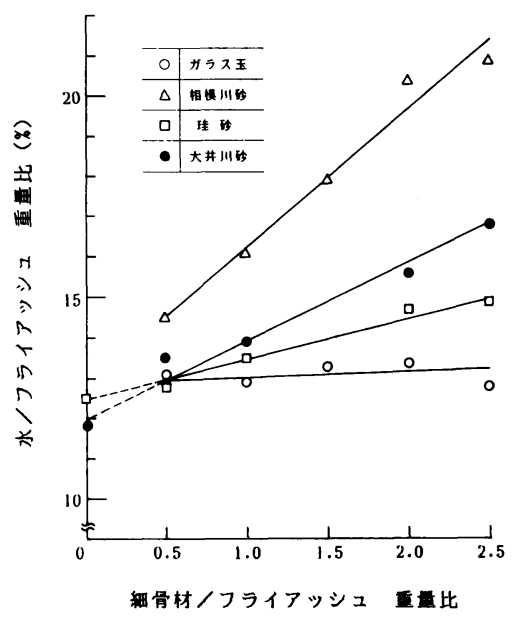

図一4 遠心力作用後の混合物中の含水率と細骨材/分散材

重量比の関係（フライアッシュ）

量で除した混合物中の含水率が増す傾向は，相模川砂ほ ど著しくないが，珪砂および大井川砂についても等しく 認められるのである。そして，混合物中の含水率と細骨 材重量を分散材重量で除した值との間には，ほぼ直線関 係の成立することが認められ，これらの直線を延長して 縦軸と交差する点が, 細骨材を含まない分散材自体の含 水率を示すことになる，データがばらついているため， 図-4の 4 本の直線は 1 点で交わっていないが, これら は, 本来縦軸上で 1 点に収束するものと考えられる.

細骨材の割合が増加しても，分散材自体が拘束して保 有している水量は，実用上変化しないと仮定できること から，細骨材量の相対的な增加に伴って混合物中の含水 率が増加することは, 細骨材が拘束して保有している水 分の存在することを示唆するものである.この保有水を, 本研究では細骨材の保有水と称することにする. 保有水 の実体は，細骨材中に含まれる JIS の吸水率に相当す る内部の水と細骨材の表面に保有されている表面吸着水 を合計したものと考える.したがって，図一4に示すよ うに，混合物中の含水率と細骨材・分散材比との間には 直線関係が成立すると仮定し，この直線の勾配は，細骨 材の保有水を細骨材の重量で除した，保有水率を示すこ とになる.

\section{6. 遠心力の影警}

遠心分離機の回転数を変えて, 試料に作用する遠心力 の大きさを最大で $1000 \mathrm{~g}$ ( $\mathrm{g}$ は重力加速度 $)$ まで変化 させた場合の川砂の保有水率を図一5に示す．遠心力の 作用時間は 30 分間で, 分散材にはフライアッシュある いは普通ポルトランドセメントを用いた，遠心力が 300 $g$ 程度までは, 遠心力の増加とともに保有水率は減少す

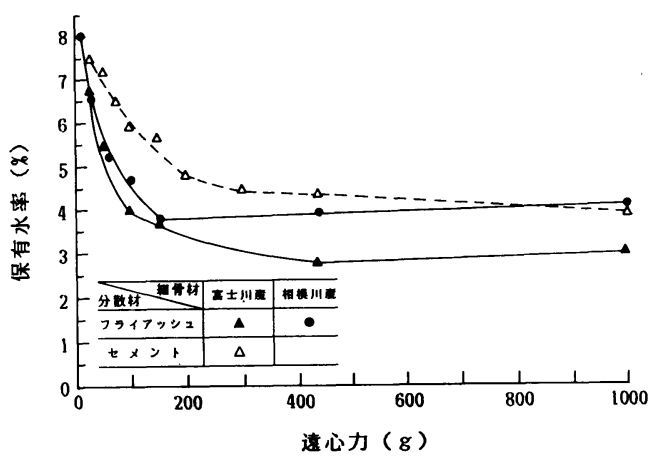

図一5 保有水來に及ぼす遠心力の影䟧

るが, 遠心力が $300 \mathrm{~g}$ 程度を超えると, 保有水率に及ほ す遠心力の大きさの影響は非常に小さいことが，いずれ の場合にも認められる.

\section{7. 分散材の影得}

分散材としての高炬スラグ微粉末の粉末度を変化させ た場合を，図一6および図一7に示す，図一6は，438g の遠心力を 30 分間作用させた後の混合物中の含水率と 細骨材/分散材重量化の関係を，また図一7は，これら の関係における直線の勾配である保有水率と高炬スラグ 微粉末の比表面積の関係を，それぞれ示している。細骨 材には，ふるい目が 0.6〜1.2 mm の間の粒径にふるい 分けた相模川砂とガラス玉を用いた。水と高炉スラグ微 粉末の重量比を $40 \%$ と一定にし，絶乾状態の細骨材に 水を重量比で $5 \%$ 混合したものを, 細骨材と高炬スラ グ微粉末の比率が所定の值になるように混合した。

比表面積が $3290 \mathrm{~cm}^{2} / \mathrm{g}$ の高炉スラグ微粉末を分散材 に用いた場合，ガラス玉が増加しても，混合物中の含水 率にはほとんど変化が認められない.しかしながら，分

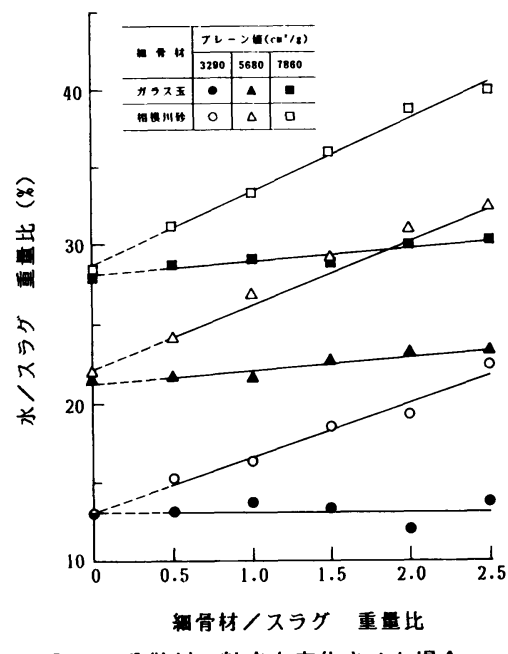

図一6分散材の粒度を变化させた場合 


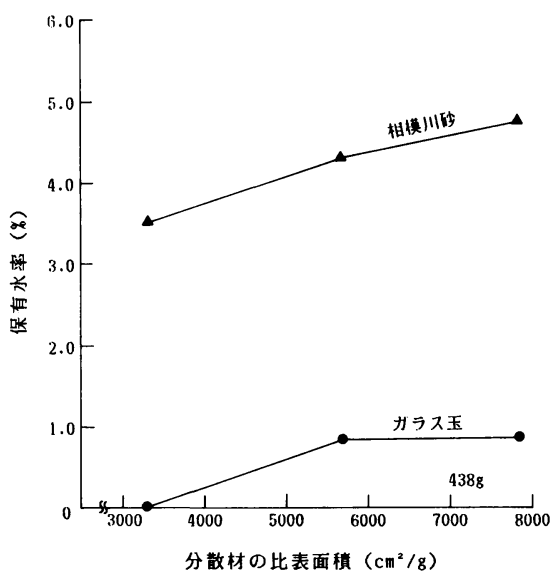

図一7 分散材の粒度と保有水率の関係

散材の比表面積を $5680 \mathrm{~cm}^{2} / \mathrm{g}, 7860 \mathrm{~cm}^{2} / \mathrm{g}$ と増加させ ると, 分散材自体の含水率だけでなく, 直線の勾配であ るガラス玉の保有水率もわずかながら増加している.こ の傾向は, 相模川砂を用いた場合には, より明暸に認め られる. 分散材の粒度が細かくなるほど, 分散材自体の 含水率が増すとともに, 細骨材の保有水率は大きく算定 される.

分散材として, フライアッシュ, 高炬スラグ微粉末お よび普通ポルトランドセメントを用いた場合を図—8に 示す. 比表面積は $3080 \sim 3760 \mathrm{~cm}^{2} / \mathrm{g}$ と, ほぼ等しい粒 度のものである.細骨材は粒度調整した相模川砂である. 横軸に, 細骨材と分散材の比率を重量比で示したものが (a) 図であり, 細骨材と分散材の重量比が 2.0 までの

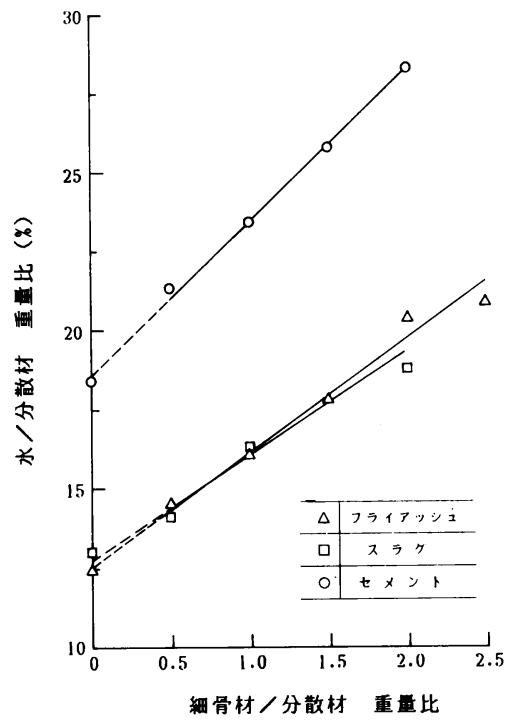

（a）重量比
ものを容積比で示したものが (b) 図である.

フライアッシュと高炬スラグ微粉末では, 分散材自体 の含水率とともに, 細骨材の保有水率を示す直線の勾配 も, 重量比で表示した場合には, ほぼ等しい値となる. しかしながら, 両者の比重が異なるため, 容積比で表示 した場合には, 分散材自体の含水率は高炬スラグ微粉末 の方が大きいが，細骨材の保有水率は，フライアッシュ の方が少し大きく算定される.

普通ポルトランドセメントを分散材とする場合には, 重量比および容積比のいずれの表示によっても, 分散材 自体の含水率および細骨材の保有水率のいずれとも, フ ライアッシュおよび高炬スラグ微粉末に比べても，大き く算定される.

本研究で提案する, 分散材を用いて細骨材を分散させ た状態で式験する方法は，細骨材と分散材が接触するた め, 細骨材の保有水にはこれらの接触水が含まれる.そ のため, 分散材の種類および粒度によって, 得られる保 有水率が異なることになる. 分散材の選定が今後の課題 となる.

\section{8. 保有水率と吸水率との関係}

遠心力を利用して求めた細骨材の保有水率と JIS A 1109 による吸水率との関係を図一9に示す。遠心力は $438 g$ を 30 分間作用させた場合である. 細骨材の種類 は, JIS の吸水率の小さいものから大きい順に, ガラス 玉, 理砂, 大井川砂および相模川砂であり, それぞれ図 ー1に示す粒度分布に調整したものである.図一10には， 表一1に示す品質をもつ実用されている粒度分布の細骨

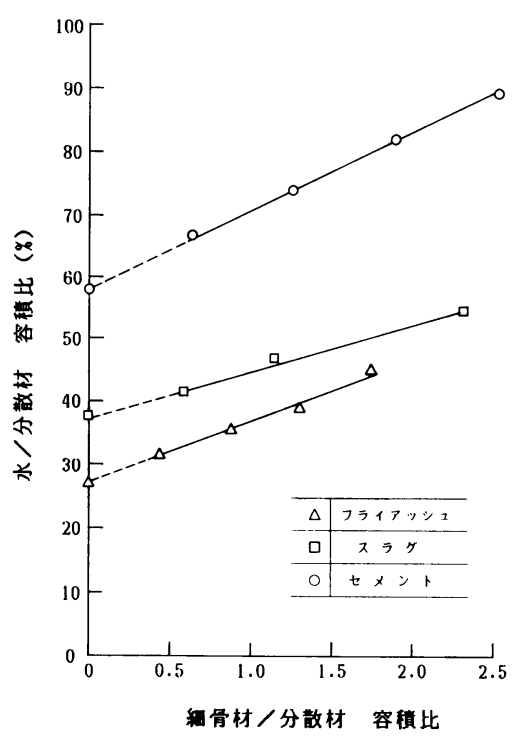

（b）容積比 


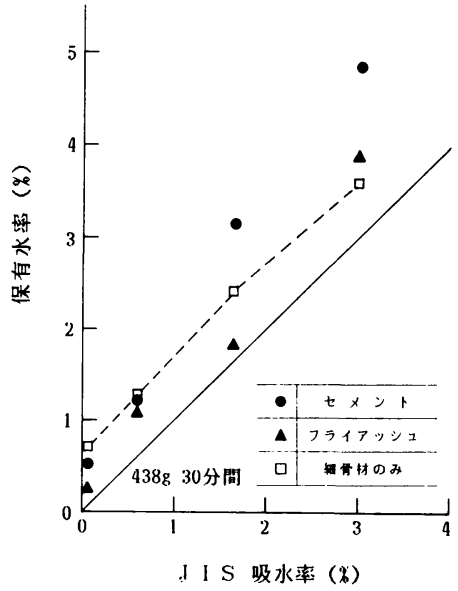

図一9 保有水率と JIS 吸水率の関係 (粒度調整をした細骨材を用い た場合）

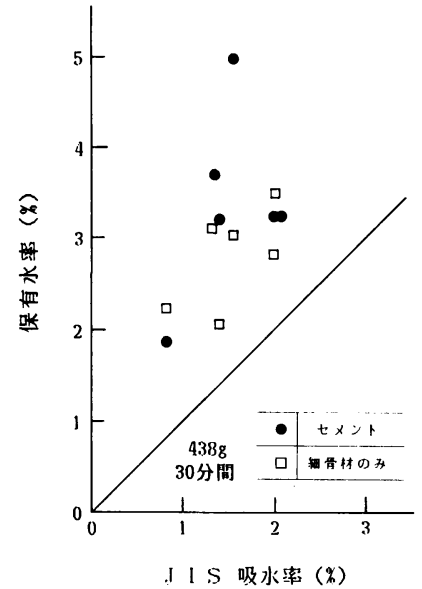

図一10 保有水率と JIS 吸水率の関係 (粒度無調整の細骨材を用い た場合）

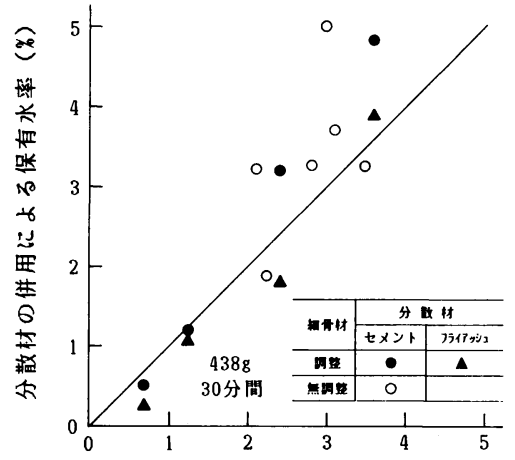

細骨材のみによる保有水率（\%)

図一11 分散材の有無が保有水率に及ぼす 影需
材について示している.また,図一9および図一10 のデー 夕から，横軸に細骨材のみの試料により求めた保有水率 をとり, 縦軸の分散材を用いて求めた保有水率と対比し て示したのが図一11である.

JISによる吸水率に比べて，いずれの細骨材とも，保 有水率は大きくなっている。そして，7.に述べたように， 分散材にセメントを用いた方が, フライアッシュの場合 より，大きな保有水率が得られている.

図一9 の破線および図一10 の白抜きの点は，分散材を 用いない細骨材と水の混合物を試料として求めたもので ある.この場合には，4. で述べたように，細骨材同士 の接触水が実測值に含まれている.このように分散材を 用いないで求めた保有水率も, 吸水率より大きな值を示 している.

図一11より，保有水率自体が小さい細骨材では，分 散材を用いて求めた保有水率は, 細骨材之水の混合物か ら求めた保有水率に比べて, 少し小さい值を示すのに対 して, 保有水率自体が大きい細骨材では, 反対に大きな 値となっている．特に分散材としてセメントを用いた場 合には, 両者の差が $2 \%$ 程度異なっている細骨材もある. このような相違は, 分散材により細骨材を相互に分離し た状態で求める本研究で提案する場合に生じる分散材と 細骨材の接触水の量が，分散材を用いない場合に生じる 細骨材相互の接触水のそれと異なることによるものと考 えられる.

\section{9. 結}

論

細骨材には，JIS で定義されている吸水率に相当する 水に加えて, その表面に拘束されている表面吸着水が存 在するとし、これがコンクリートの品質に影響を及ぼす
ものと考えて, 吸水率に相当する水と表面吸着水を合計 した細骨材の保有水を試験する方法の基本的な概念を提 案し，この方法を用いた場合の基礎的な実験結果を報告 した. 本研究の範囲内で次のことがいえると思われる.

（1）遠心力作用後の混合物中の含水率は, 細骨材と 分散材の重量比の増加とともにほぼ直線的に増加し, こ の直線の勾配を, 細骨材の保有水率と定義することがで きる.

（2）細骨材を分散材中に分散させた状態で遠心力を 作用させる本試験方法は, 細骨材相互の接触水の影響を 除外したことにより，すでに著者らの一人が提案してい る細骨材と水の混合物を試料とする方法に比べて, 改善 されたものと考えられる.

（3）細骨材や分散材の種類, 遠心力の作用時間など により異なるが, 重力加速度の 300 倍程度の遠心力を 30 分間程度以上作用させても, 細骨材の保有水率はほ とんど減少しなくなる。

（4）本試験方法は，分散材により細骨材相互が接触 されていない実際のモルタルの性状をより正確にモデル 化できるもので, 分散材にセメントを用いると, 実際の フレッシュモルタルの品質を試験することができる.

（5）分散材の種類や粒度により, 細骨材の保有水率 が異なるため, 表面形状等の異なる各種細骨材相互の保 有水を統一的に評価するため, あるいは実際のモルタル 中における細骨材の保有水を定めるためなど，その目的 に応じた分散材の選定が必要となってくる．この点につ いては今後研究を進めていきたい.

謝辞：本研究の実施に際しては，大成建設（株） 技術研究所より多大なるご協力を頂いた。 また高炉スラ 
グ微粉末の B 2，B 3，B 4 は，新日本製鉄（株）より ご提供頂いた。付記して厚くお礼申し上げます.

参 考 文 献

1）原島・剣持・伊東：高強度スラリーモルタルの特性につ いて, 土木学会第 33 回年次学術講演会講演概要集第 5 部, $\mathrm{V}-114$, 昭和 53 年 9 月.

2）魚本健人：分割方式によるコンクリートの練り混ぜ方法 に関する基礎的研究，コンクリート工学, Vol. 20,
No. 9, pp. 99 114, Sept. 1982.

3）伊東靖郎：細骨材の水と空気による界面状態がコンク リートおよびモルタルに及ぼす影響に関する研究，土木 学会論文報告集, 第 343 号, pp. 229 238, 1984 年 3 月.

4）吉兼・鯉江・中島：遠心脱水による細骨材の表面乾燥内 部飽水状態について，セメント・コンクリート，No. 444， pp. 40 47, Feb. 1984.

(1986.10.31 - 受付) 